\title{
Production, purification and characterization of L-Glutaminase from Streptomyces sp. isolated from soil
}

\author{
Savitha S. Desai, Sonal J. Chopra, Basavaraj S. Hungund* \\ Department of Biotechnology, B. V. Bhoomaraddi College of Engineering and Technology, Hubballi-580031, India.
}

\begin{tabular}{l} 
ARTICLE INFO \\
\hline Article history: \\
Received on: $24 / 05 / 2016$ \\
Revised on: 11/06/2016 \\
Accepted on: 03/07/2016 \\
Available online: 28/07/2016 \\
\hline Key words: \\
L-Glutaminase, \\
Actinomycetes, Streptomyces \\
sp, ion exchange \\
chromatography, SDS- \\
PAGE.
\end{tabular}

\begin{abstract}
L-Glutaminase, an amidohydrolase enzyme has been a choice of interest in the treatment of lymphoblastic leukaemia. The present study reports production, purification and characterization of extracellular glutaminase enzyme from Actinomycetes. Screening was performed for twenty Actinomycetes isolates from soil; one isolate (Isolate 2) was finally selected based on the activity of glutaminase $(32.5 \mathrm{U} / \mathrm{ml})$. The isolate was identified as Streptomyces sp. Effect of physicochemical factors namely temperature, $\mathrm{pH}, \mathrm{NaCl}$ concentration, and supplementary carbon \& nitrogen sources on the production of L-glutaminase from the Streptomyces sp. was carried out. The enzyme production was found to be optimum with glucose as carbon source $(33 \mathrm{U} / \mathrm{ml})$, Lglutamine as nitrogen source $(33.1 \mathrm{U} / \mathrm{ml})$, at $7 \mathrm{pH}(32.8 \mathrm{U} / \mathrm{ml})$, temperature $30^{\circ} \mathrm{C}(32.4 \mathrm{U} / \mathrm{ml})$ and for $0.1 \%$ $\mathrm{NaCl}$ concentration $(32.5 \mathrm{U} / \mathrm{ml})$. The L-glutaminase produced from Streptomyces sp. was purified by ammonium sulphate precipitation, dialysis method and ion exchange chromatography. After the purification of the enzyme by ion exchange chromatography, it has been purified 46 -fold from cell-free extract and yield was $3.25 \%$. Characterization of extracellular L-glutaminase showed that the enzyme shown optimal activity at temperature of $30^{\circ} \mathrm{C}, \mathrm{pH} 7$, at $2 \% \mathrm{NaCl}$ and for $0.04 \mathrm{M}$ substrate and the $\mathrm{Km}$ value was calculated to be $2.8 \mathrm{mM}$ and $\mathrm{V}_{\max }$ was $7.57 \mathrm{U} / \mathrm{ml}$. The molecular weight of enzyme as determined by sodium dodecyl sulphate polyacrylamide electrophoresis (SDS-PAGE) was found to be $50 \mathrm{kDa}$.
\end{abstract}

\section{INTRODUCTION}

Enzymes are biocatalysts produced by living cells to bring about specific biochemical reactions generally forming parts of the metabolic processes of the cells. L-glutaminase (Lglutamine amido hydrolase EC 3.5.1.2) enzyme has attracted significant attention owing to its potential application in medicine as an anticancer agent and could be of significance in enzyme therapy of acute lymphocytic leukaemia. In recent years, L-glutaminase has attracted much attention in both pharmaceutical and food industrial applications. Microbial Lglutaminases are preferred for food and pharmaceutical uses because its production is rapid, inexpensive, gentle, and compatible with downstream steps of its purification (Singh

\footnotetext{
* Corresponding Author

Email: :hungundb@gmail.com
}

and Banik, 2013). In food industry, L-glutaminase is used as a flavour enhancer by increasing glutamic acid content in food through hydrolysis of L-glutamine to L-glutamic acid and ammonia. Its commercial importance demands the search for new and better yielding microbial strains and economically viable bioprocesses for its large-scale production (Iyer and Singhal, 2009).

L-Glutamine is used as obligate nitrogen donor for the biosynthesis of purine and pyrimidine nucleotides in a living cell. Tumor cells have no mechanism to synthesize L-glutamine and hence take it as an exogenous source. L Glutaminase causes selective death of glutamine-dependent tumor cells by depriving cells with L-glutamine, and hence it is used as an effective agent in the treatment of acute lymphocytic leukemia and HIV (Singh and Banik, 2013). Actinomycetes are aerobic gram positive filamentous bacteria with high $\mathrm{G}+\mathrm{C}$ content which form asexual spores and which are widely distributed in both terrestrial and aquatic habitats. 
Actinomycetes are well recognized to produce a variety of chemical structures, which are most valuable for pharmaceuticals, agrochemicals and industrial products like enzymes. The value of Actinomycetes to society in terms of providing useful drugs especially antibiotics and anticancer agent and to the pharmaceutical industry for revenue generating discovery platform, is indisputable (Okami, 1986). Actinomycetes are the main source of clinically important antibiotics, most of which are too complex to be synthesized by combinatorial chemistry and which are ecofriendly filamentous bacteria. Since the sources for L-glutaminase are limited, the search for potential microbial strains that hyper produce the enzyme with novel properties for their industrial production is being pursued all over the world (Prabhu and Chandrasekaran, 1995). Glutaminase is also taking an important role that controls the delicious taste of fermented foods such as soy sauce and in general food products by increasing the glutamic acid content therefore, this enzyme has attracted a great attention in food industries (Moriguchi et al., 1994). In present study, we reported production, purification and characterization of L-Glutaminase from Actinomycetes.

\section{MATERIAL AND METHODS}

\section{Microorganism and Culture Condition}

The Actinomycetes isolates were grown in Asparagine Glucose media (AG media g/l 0.5 L-Asparagine; Glucose 10; $\mathrm{KH}_{2} \mathrm{PO}_{4} 0.5$; Agar 2) at $\mathrm{pH}$ 7. The isolates were inoculated in same broth for further studies and maintained in same medium slants at $4 \pm 1^{\circ} \mathrm{C}$ and sub-cultured every 30 days. The production of Lglutaminase has been studied in a production medium $(\mathrm{pH} 7.5)$ containing Glucose $(0.2 \%)$, L-glutamine $(0.5 \%), \mathrm{Na}_{2} \mathrm{HPO}_{4} \cdot 2 \mathrm{H}_{2} \mathrm{O}$ $(0.6 \%), \mathrm{KH}_{2} \mathrm{PO}_{4}(0.3 \%), \mathrm{NaCl}(0.05 \%), \mathrm{MgSO}_{4} \cdot 7 \mathrm{H}_{2} \mathrm{O}(0.05 \%)$, $\mathrm{CaCl}_{2} \cdot 2 \mathrm{H}_{2} \mathrm{O}(0.0015 \%)$, and Peptone $(0.2 \%)$. Fermentation was carried out and incubated at $27^{\circ} \mathrm{C}$ for 6 days in an orbital shaker at $150 \mathrm{rpm}$. The fermented broth was centrifuged at $10,000 \mathrm{rpm}$ at 4 $\pm 1{ }^{\circ} \mathrm{C}$ for $15 \mathrm{~min}$, and the supernatant was used as the enzyme (Singh and Banik, 2013). Screening was done for enzyme production by all the isolates. The physiological and biochemical characteristics of isolate 2 were monitored according to standard methods of starch hydrolysis, cellulose hydrolysis, gelatin hydrolysis, casein hydrolysis, $\mathrm{H}_{2} \mathrm{~S}$ production, nitrate reduction, catalase production, milk peptonization and utilization of carbon and nitrogen sources (Shirling and Gottileb, 1966). Further the isolate was identified as Streptomyces sp. based on its biochemical properties.

\section{Assay of L-Glutaminase}

L-glutaminase activity was determined using Lglutamine as substrate and estimating the product ammonia released by Berthelot reaction. An aliquot of $0.5 \mathrm{ml}$ of the sample was mixed with $0.5 \mathrm{ml}$ of $0.04 \mathrm{M} \mathrm{L-glutamine} \mathrm{solution} \mathrm{and} 0.5 \mathrm{ml}$ of phosphate buffer $(0.1 \mathrm{M}, \mathrm{pH} 7.0)$. Then the mixture was incubated at $37^{\circ} \mathrm{C}$ for $15 \mathrm{~min}$ and the reaction was arrested by the addition of $0.5 \mathrm{ml}$ of $1.5 \mathrm{M}$ Trichloro-Acetic Acid. To $0.5 \mathrm{ml}$ of the mixture, $1.5 \mathrm{ml}$ of distilled water, $1 \mathrm{ml}$ of phenol reagent, $1 \mathrm{ml}$ of $1 \mathrm{~N} \mathrm{NaOH}$ and $1 \mathrm{ml}$ of alkaline hypochlorite. A tube containing $2 \mathrm{ml}$ of distilled water serves as the blank. Mix the contents of the tubes by vortexing / shaking the tubes and incubate for $15 \mathrm{~min}$ at room temperature. The absorbance was measured at $600 \mathrm{~nm}$ using a spectrophotometer. Then a standard graph was plotted using ammonium chloride as the standard for computation of the concentration of ammonia, liberated due to enzyme activity. One international unit of L-glutaminase was defined as the amount of enzyme that liberates one $\mu \mathrm{M}$ of ammonia under optimum conditions (Sabu et $a l ., 2000$ ).

\section{Optimisation for L-Glutaminase Production}

Initially, various physicochemical parameters required for maximum L-glutaminase production by Streptomyces sp. were optimized. As a first optimization step, the critical variables for Lglutaminase production along with their variation ranges were estimated based on classical 'one-variable-a-time' approach. The effect of $\mathrm{pH}$ (ranging from 5-7), incubation temperature (25$40^{\circ} \mathrm{C}$ ), and different carbon sources (glucose, sucrose and fructose) at $0.2 \%$ concentration, nitrogen sources (urea, peptone and 1glutamine) at $0.7 \%$, and effect of sodium chloride (ranging from $0.05 \%-0.15 \%$ ) were investigated. All experiments were conducted in at least triplicate, and the mean values are calculated (Iyer and Singhal, 2009).

\section{Enzyme Purification and Quantification}

Finely powdered ammonium sulfate was added with constant stirring to the supernatant of fermented broth obtained after centrifugation and was incubated overnight at $4^{\circ} \mathrm{C}$. Maximum L-glutaminase activity was observed with the fraction precipitated at $60-80 \%$ saturation. The Sample after centrifugation was dialyzed against the phosphate buffer for $24 \mathrm{~h}$. Further dialyzed sample was subjected to anion exchange chromatography on a Diethylaminoethyl (DEAE)-cellulose column, pre-equilibrated same buffer. The column was washed thoroughly with the same buffer, and the bound proteins were eluted with a linear salt gradient of $\mathrm{NaCl}(0.1-0.25 \mathrm{M})$. All the fractions were assayed for L-glutaminase activity. Sodium dodecyl sulfate (SDS)-PAGE was performed and the molecular weight of L-glutaminase was determined using standard molecular weight markers.

\section{Enzyme Characterization}

The L-glutaminase was characterised for its various properties. The characters analysed included effect of $\mathrm{pH}(5-9)$ and temperature $\left(20-60^{\circ} \mathrm{C}\right)$ on enzyme activity and stability, effect of $\mathrm{NaCl}(1-5 \%)$ on enzyme activity, effect of substrate concentration ( $\mathrm{L}$-glutamine; $0.01-1.0 \mathrm{M}$ ) on enzyme activity.

\section{RESULTS}

\section{Screening of L-Glutaminase Producers}

The Qualitative screening of the isolates of Actinomycetes for the synthesis of L-glutaminase showed intense 
colour change from yellow to pink colour in MGA media. The isolates Isolate 1 and Isolate 2 showed the intense colour change indicating potent enzyme production in figure.1.

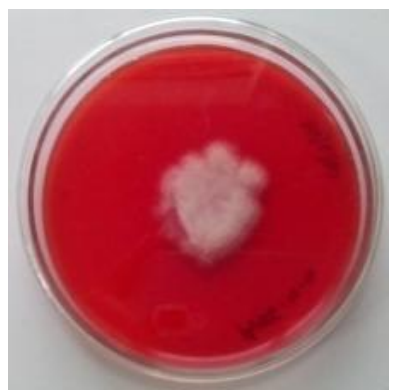

(A)

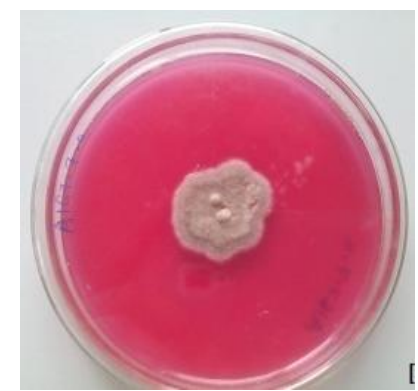

(B)

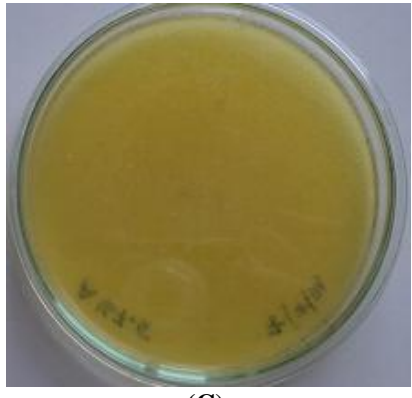

(C)

Fig. 1: Qualitative screening for L-Glutaminase production by isolate 2, Streptomyces sp. (A) and isolate 1 (B). The plates show change in colour of MGA medium from yellow to pink due to production of enzyme. Control plate shows yellow colour of the medium (C).

\section{Identification and Characterization of the Isolate}

The colony belonged to the genus Streptomyces since the colony was slow growing, aerobic, heaped, folded and with aerial. In addition, colony possessed an earthy odour. A confirmatory identification to genus was based on acid-fastness, Gram-stain. The Streptomyces strain was acid-fast negative and Gram-stain positive. The results indicated that the tested isolate 2 was able to hydrolysis starch, decompose cellulose, liquefy gelatin, and produce catalase.

The tested isolate utilized D-glucose, D-fructose, Dgalactose, D-xylose, and sucrose as carbon source for its growth, but it was unable to grow on L-arabinose, L- rhamnose and lactose. On the other hand, the tested isolate 2 was able to grow on L-glutamine, L-tryptophane, L-tyrosine, L-glycine, L-asparagine, L-cystine, L-phenyl alanine, L-histidine, L-hydroxyproline, and Llysine as nitrogen source for its growth. Based on the characteristics described above, the isolate 2 was assigned to the genus Streptomyces.

\section{L-Glutaminase Production from Actinomycetes by Submerged Fermentation}

The selected Actinomycetes were further taken for enzyme production which was carried out in shake flask in submerged fermentation. The continuous 6 days analysis was done for enzyme production by calculating enzyme activity by indophenol blue method. The isolated Actinomycetes
Streptomyces sp., Isolate 1 showed high enzyme activity as 32.5 $(\mathrm{U} / \mathrm{mL})$ and $23.6(\mathrm{U} / \mathrm{mL})$ on $5^{\text {th }}$ day as shown in figure 2 .

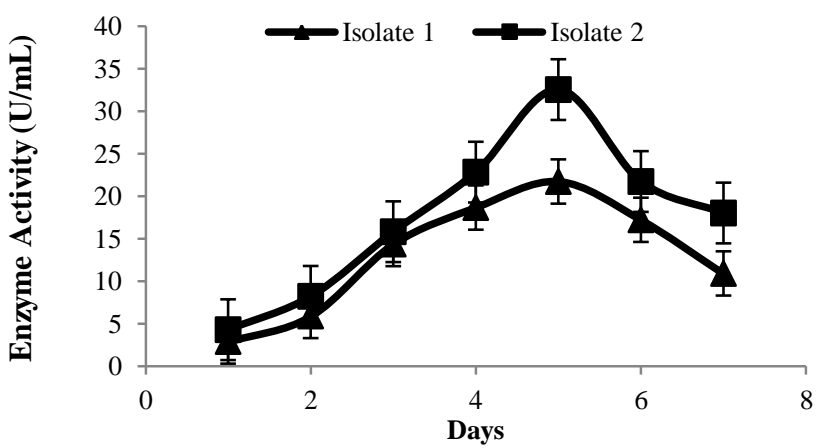

Fig. 2: Graph showing profile of enzyme activity Vs incubation time (Isolate 1 and Isolate 2).

\section{Optimisation for L-Glutaminase Production}

Carbon acts as an important factor for the enzyme production. Among the various carbon sources, glucose gave the high enzyme activity of $33 \mathrm{U} / \mathrm{ml}$. Nitrogen can be an important limiting factor for the microbial production of enzymes. The nitrogen source which gave highest enzyme activity of $33.1 \mathrm{U} / \mathrm{ml}$ was the substrate i.e., L-glutamine. Almost every biological process was $\mathrm{pH}$ dependent; a small variation in $\mathrm{pH}$ had changed the rate of production. Hence, the optimal $\mathrm{pH}$ was very important for maximizing the yield of L-Glutaminase production. Neutral $\mathrm{pH}$ $(\mathrm{pH}=7)$ gave the maximal enzyme yield $(32.8 \mathrm{U} / \mathrm{ml})$ when compared to the remaining $\mathrm{pH}$. The optimum enzyme activity is $32.4 \mathrm{U} / \mathrm{mL}$ at $30^{\circ} \mathrm{C}$ and $32.5 \mathrm{U} / \mathrm{mL}$ at $0.1 \% \mathrm{NaCl}$ concentration Lglutaminase production was optimum. Therefore, the enzyme production from the Streptomyces $s p$ in the production media was found optimal for glucose as carbon source $(33 \mathrm{U} / \mathrm{ml})$ and 1glutamine as nitrogen source $(33.1 \mathrm{U} / \mathrm{ml})$ at $7 \mathrm{pH}(32.8 \mathrm{U} / \mathrm{ml})$, $30^{\circ} \mathrm{C}(32.4 \mathrm{U} / \mathrm{ml})$ and for $0.1 \% \mathrm{NaCl}$ concentration $(32.5 \mathrm{U} / \mathrm{ml})$ as shown in table 1 .

Table 1: Effect of different parameters on L-Glutaminase production by Streptomyces sp.

\begin{tabular}{|c|c|}
\hline Parameters & Enzyme Activity (U/mL) \\
\hline \multicolumn{2}{|l|}{ Carbon Source } \\
\hline Glucose & 33 \\
\hline Sucrose & 26.98 \\
\hline Fructose & 21.84 \\
\hline \multicolumn{2}{|l|}{ Nitrogen Source } \\
\hline L-glutamine & 33.1 \\
\hline Peptone & 11.68 \\
\hline Urea & 17.78 \\
\hline \multicolumn{2}{|l|}{ pH } \\
\hline 5 & 12.08 \\
\hline 6 & 19.9 \\
\hline 7 & 32.8 \\
\hline \multicolumn{2}{|l|}{ Temperature } \\
\hline 25 & 11.9 \\
\hline 30 & 32.4 \\
\hline 35 & 5.3 \\
\hline \multicolumn{2}{|l|}{$\mathrm{NaCl}$} \\
\hline 0.05 & 26.64 \\
\hline 0.1 & 32.5 \\
\hline 0.5 & 29.76 \\
\hline
\end{tabular}




\section{Enzyme Purification}

The procedure and results of purifying glutaminase from the Streptomyces sp. are summarized in table 2. By ammonium sulphate precipitation, the glutaminase was purified approximately 4 times more, and the yield rate was enhanced up to $23.4 \%$. To purify the enzyme further, weak anion exchange chromatography was carried out. A total of 40 fractions were eluted with $\mathrm{NaCl}$ gradient ranges from 0.1 to $0.25 \mathrm{M}$. Among the fractions, the highest activity of $2.89 \mathrm{U} / \mathrm{mL}$ was obtained when $0.20 \mathrm{M} \mathrm{NaCl}$ was used in elution buffer. On the other hand, very low glutaminase activity was detected in a range of 0.1 to $0.15 \mathrm{M}$ $\mathrm{NaCl}$, and the low activity of $0.164 \mathrm{U} / \mathrm{mL}$ was shown in the 0.25 $\mathrm{M} \mathrm{NaCl}$ fraction. The yield and the final specific activity were $3.25 \%$ and $27.6 \mathrm{U} / \mathrm{mL}$, respectively. The result of SDS-PAGE after the final step of purification revealed a single major band corresponding to molecular mass of approximately $50 \mathrm{kDa}$.

Table 2: Table showing protein content, specific activity, total activity and yield for L-Glutaminase from Streptomyces sp. during sequential purification stages.

\begin{tabular}{|c|c|c|c|c|c|}
\hline METHOD & 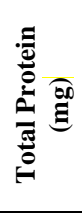 & 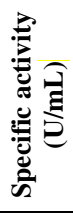 & 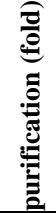 & 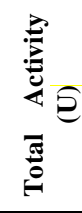 & $\stackrel{ }{Ð}$ \\
\hline Crude extract & 138.7 & 0.2 & 1 & 2883 & 100 \\
\hline Ammonium sulphate $(70 \%)$ & 153.67 & 0.29 & 1.45 & 676.05 & 23.4 \\
\hline Dialysis & 51.3 & 0.6 & 2.06 & 156.8 & 5.4 \\
\hline Ion exchange chromatography & 1.7 & 27.6 & 46 & 93.8 & 3.25 \\
\hline
\end{tabular}

\section{Enzyme Characterization}

The L-glutaminase activity was characterized by testing its activity for various parameters. L-glutaminase activity was optimum at $2 \%$ of $\mathrm{NaCl}$ concentration and the activity considerably decreased at both low $\mathrm{NaCl} \%$ and high $\mathrm{NaCl} \%$. Results are represented in table 3. The glutaminase from Streptomyces sp. preferred $30^{\circ} \mathrm{C}$ as its optimum temperature. However, it retained $75 \%$ of the activity over a temperature range of $20-60^{\circ} \mathrm{C}$ and was stable up to $60^{\circ} \mathrm{C}$. A substrate concentration at $0.04 \mathrm{M}$ was found to have higher enzyme activity and the $\mathrm{Km}$ value was calculated to be $2.8 \mathrm{mM}$ and $\mathrm{V}_{\max }$ is $7.57 \mathrm{U} / \mathrm{ml}$. The enzyme was active over a range of $\mathrm{pH} 5-9$ with optimum at $\mathrm{pH}$ 7.0. The activity considerably decreased at both low $\mathrm{pH}(5.0)$ and high $\mathrm{pH}(10.0)$.

Table 3: Table showing effect of parameters on L-Glutaminase activity (Enzyme characterization studies).

\begin{tabular}{cc}
\hline Parameters & Mean Enzyme Activity (U/mL) \\
\hline Concentration of $\mathbf{~ N a C l ~ ( w / v ~ \% ) ~}$ & \\
\hline 1 & 31.2 \\
2 & 33.2 \\
3 & 32.4 \\
4 & 30.2 \\
5 & 29.7 \\
\hline Substrate (M) \\
\hline 0.01 & 23.3 \\
0.02 & 23.8 \\
0.03 & 31.5
\end{tabular}

\begin{tabular}{ccc}
0.04 & 32.4 \\
0.05 & 29.3 \\
0.06 & 29.2 \\
0.07 & 28.8 \\
0.08 & 27.1 \\
0.09 & 25.5 \\
0.1 & 23.6 \\
0.2 & 23.22 \\
0.25 & 20.22 \\
0.5 & 19.3 \\
1 & 19.5 \\
\hline pH & \\
\hline & 5 & 27.7 \\
6 & 28.8 \\
7 & 32.5 \\
& 30.5 \\
9 & 27.2 \\
\hline Temperature & \\
\hline 20 & 29.5 \\
30 & 32.4 \\
40 & 28.1 \\
50 & 27.3 \\
60 & 24.3 \\
\hline
\end{tabular}

\section{DISCUSSION}

The screening of Actinomycetes is based on the semi qualitative method described by Gulati et al (1997). The colour change of the medium from yellow to pink is an indication of the extra cellular L-glutaminase production by the colony. This colour change is due to change in the $\mathrm{pH}$ of the medium, as $\mathrm{L}$ glutaminase causes the breakdown of amide bond in L-glutamine and liberates ammonia. Phenol red at acidic $\mathrm{pH}$ is yellow and at alkaline $\mathrm{pH}$ turns pink, thus a pink zone is formed around the microbial colonies producing L-glutaminase. The results were those in agreement with various workers like Dutt et al. (2010) who worked on Pencillium expansum KGSS08 which exhibited higher zone of diameter and was considered as a potential strain of L-glutaminase producer among the strains isolated from soil. These results were close agreement with the reports of Gulati et al. (1997).

Several reports are available on the process standardization by submerged system and solid state system for the production of L-glutaminase by employing either bacterial or fungal cultures. Relatively, not much information is available regarding the production of L-glutaminase by Actinomycetes. Das and Agsar (2013) reported similar results on the production of Lglutaminase by all the isolates which gradually increased from 24 hrs to 120 hrs and then no more increase was observed.

Among the various carbon sources, glucose promoted both biomass and glutaminase production. This is in accordance to earlier reports on the preference of marine organisms for slowly utilizable sugars like glucose. Lactose, citric acid, sucrose, mannitol, and maltose decreased both the glutaminase activity as well as the biomass. When free sugars were eliminated from the medium, there was production of both biomass and activity $(65.74$ U/l). This indicated the ability of the organism to utilize other media components for energy (Iyer and Singhal, 2009). Das and Agsar (2013) reported that L-glutamine act as the optimum nitrogen source $(30.24 \pm 0.01 \mathrm{IU})$ among all sources tested. Quite 
similar results were found with the previous researchers Banik and Singh (2011), Sathish et al. (2008). It depicts that, indeed the amide nitrogen of glutamine was source of amino groups in a wide range of biosynthetic processes and it also frequently involved in protein active or binding sites.

Neutral $\mathrm{pH}(\mathrm{pH}=7)$ gave the maximal enzyme yield (45.8 $\mathrm{U} / \mathrm{ml}$ ) when compared to the remaining $\mathrm{pH}$ values (table 1 ). The pH 7 was also the optimum for maximum L-glutaminase activity from marine Micrococcus luteus as reported by Moriguchi et al. (1994). The maximum L-Glutaminase activity 46 IU was obtained at pH 7.0 by Rashmi et al. (2012).

The optimum temperature for the enzyme activity was found to be 30 to $40^{\circ} \mathrm{C}$, at which the enzyme activity was the highest. Similar observations were reported for glutaminase from Trichoderma koningii which produced $15.59 \mathrm{U} / \mathrm{gds}$ at $33^{\circ} \mathrm{C}(\mathrm{El}-$ Sayed, 2009). With prolonged incubation, enzyme activity decreased sharply suggesting that the end-point of fermentation should be carefully controlled because the synthesized enzyme could be degraded by non-specific proteases secreted by the fungus. Sinha and Nigam (2016) reported production of Lglutaminase by Bacillus sp. and identification of the isolate was done by $16 \mathrm{~S}$ rRNA sequencing. They speculated this highly stable enzyme from Bacillus sp. may be useful for biotransformation of L-glutamine and could be exploited for development of drug towards cancer therapy.

Addition of high $\mathrm{NaCl}$ to seawater in the enzyme production medium led to a decline in the enzyme production.. The data indicate that sea water could be an ideal medium or at least adequate to support L-glutaminase synthesis (Sabu et al., 2000). High salt-tolerance of L-glutaminase produced by Lactobacillus rhamnosus was reported (Weingand-Ziade et al., 2003), where the presence of $5 \%(w / v)$ salt increased Lglutaminase activity almost two-fold and $90 \%$ of the initial activity still remained at $15 \%(\mathrm{w} / \mathrm{v})$ salt.

Purification of L-glutaminase from cell-free extracts of Debaryomyces sp. CECT 11815 was achieved by ammonium sulphate treatment followed by anion exchange chromatography and gel filtration as reported by Dura et al. (2002). As reported by Dura et al., the glutaminase showed high instability especially during the gel-filtration step. Whereas, glutaminase from nonmarine microbes were found to be inactivate at high salt concentrations, limiting their industrial potential. The glutaminase can increase the amount of glutamic acid through hydrolysis of glutamine under physical stress-reinforced conditions such as elevated salt concentration or temperature. However, regarding the glutaminase of Lactobacillus rhamnosus, the relative activity was 1.8 times higher in presence of $2.5 \% \mathrm{NaCl}$, exhibiting higher activity than the control without salt (Weingand-Ziade et al., 2003). The above results suggest that glutaminase from lactobacilli can be more salt tolerant than other species that have been reported so far. In addition, the enzymes from $L$. rhamnosus (WeingandZiade et al., 2003), the glutaminase activity was detected at a $\mathrm{pH}$ range between 5.0 and 11.0, which is broader than the range from 7.5 to 9 shown by Debaryomyces spp (Dura et al., 2002) and the range from 6.0 to 9.0 by L. rhamnosus (Weingand-Ziade et al., 2003). Therefore, glutaminase can increase the amount of glutamic acid through hydrolysis of glutamine under physical stressreinforced conditions such as elevated salt concentration or temperature.

Jeon et al. (2010) observed the result of SDS-PAGE after the final step of purification which revealed two major bands corresponding to molecular mass of approximately 70 and $50 \mathrm{kDa}$. The enzyme preparation, however, still showed some minor impurities on the electrophoretogram. From these results, impurity seems to exist through SDS-PAGE because a glutaminaseassociated enzyme appears together during the separation process due to strong binding. The glutaminase from Pseudomonas $s p$. appeared to synthesize two isoenzymes of 70 and $50 \mathrm{kDa}$, which closely correlate with the deduced molecular masses of those of $L$. reuteri KCTC3594. The glutaminase purified from Micrococcus was also determined to be $49.9 \mathrm{kDa}$ (Masuo et al., 2005). Reda FM (2015) reported production of L-glutaminase from Streptomyces canarius strain FR having molecular mass of $44 \mathrm{kDa}$ and showed maximum enzyme activity at $\mathrm{pH} 8.0$ at $40^{\circ} \mathrm{C}$ incubated for $30 \mathrm{~min}$. The enzyme showed good anticancer activity against five human cancer cell lines when tested using MTT in-vitro assay.

\section{CONCLUSION}

In the present study, different Actinomycetes obtained from soil were screened for L-glutaminase production using semi qualitative method. A potential L-Glutaminase producing actinomycete was selected and further identified using morphological and Biochemical characters as Streptomyces sp. Further, effect of parameters on enzyme production by Streptomyces sp. was studied. L-Glutaminase enzyme was purified through series of purification steps involving Dialysis, Ion exchange Chromatography and SDS-PAGE and characterized for its various properties.

\section{CONFLICT OF INTEREST}

The authors have no conflict of interest to declare.

\section{ACKNOWLEDGEMENT}

The authors acknowledge Dr. Ashok Shettar, Vice Chancellor, KLE Technological University, Hubballi for his constant support and encouragement.

\section{REFERENCES}

Banik RM and Singh P. Optimization of agitation and aeration rate for maximum production of L-glutaminase by Bacillus cereus MTCC 1305. International Journal of Research, 2011; 2: 14-25.

Das M and Agsar D. Production and Antioxidant Attribute of LGlutaminase from Streptomyces enissocaesilis DMQ-24. International Journal of Latest Research in Science and Technology, 2013; 2(3): 1-9.

Dura MA, Flores M \& Toldra F. Purificaton and characterization of glutaminase from Debaryomyces spp. International Journal of Food Microbiology, 2002; 76: 117-126. 
El-Sayed ASA. L-glutaminase production by Trichoderma koningii under solid state fermentation. Indian Journal of Microbiology, 2009; 4: 243-250.

Gulati R, Saxena RK and Gupta R. A rapid plate assay for screening L-asparaginase producing microorganisms. Letters in Applied Microbiology, 1997; 24: 23-26.

Iyer PV and Singhal RS. Screening and selection of marine isolate for L-glutaminase production and media optimization using response surface methodology. Applied Biochemistry and Biotechnology, 2009; 159: 233-250.

Jeon JM , Lee HI, Han SH, Chang CS and So JS. Partial purification and characterization of glutaminase from Lactobacillus reuteri KCTC3594. Applied Biochemistry and Biotechnology, 2010; 162: $146-154$.

Masuo N, Yoshimune K, Ito K, Matsushima K, Koyama Y \& Moriguchi M. Micrococcus luteus K-3-type glutaminase from Aspergillus oryzae RIB40 is salt tolerant. Journal of Bioscience and Bioengineering, 2005; 100: 576-578.

Moriguchi M, Sakai K, Tateyama R, Furuta Y and Wakayama M. Isolation and characterization of salt-tolerant glutaminases from marine Micrococcus luteus K-3. Journal of Fermentation and Bioengineering, 1994; 77: 621-625.

Okami Y. Marine microorganisms as a source of bioactive agents. Microbial Ecology, 1986; 12: 65-78.

Prabhu G N and Chandrasekaran M. Polystyrene - an inert carrier for glutaminase production by marine Vibrio costicola under solidstate fermentation. World Journal of Microbiology and Biotechnology, 1995; 11: 683-684

Rashmi, AM, Gopinath SM., Krishan Kumar, Narashima Murthy TP. Optimization of submerged fermentation process for LGlutaminase produced by Pseudomonas aeruginosa BGNAS-5. International Journal of Latest Research in Science and Technology, 2012; 1(4): 308-310.

Reda, FM. Kinetic properties of Streptomyces canarius Lglutaminase and its anticancer efficiency. Brazilian Journal of Microbiology, 2015; 46(4): 957-968.
Sabu A, Keerthi TR, Kumar SR and Chandrasekaran M. LGlutaminase production by marine Beauveria sp. under solid state fermentation. Process Biochemistry, 2000; 35: 705-710.

Sathish T, Lakshmi GS, Rao ChS, Brahmaiah P and Prakasham RS. Mixture design as first step for improved L-glutaminase production in solid-state fermentation by isolated Bacillus sp. RSP-GLU. Letters in Applied Microbiology, 2008; 47(4): 256-262.

Shirling EB and Gottlieb D. Methods for characterization of Streptomycetes species. International Journal of Systematic Bacteriology, 1966; 16: 313.

Singh $\mathrm{P}$ and Banik RM. Biochemical Characterization and antitumor study of L-glutaminase from Bacillus cereus MTCC 1305. Applied Biochemistry and Biotechnology, 2013; 171: 522-531.

Sinha S and Nigam VK. Production and characterization of Lglutaminase by Bacillus sp. International Journal of Pharmaceutical Sciences and Research, 2016: 7(4): 1620-1626.

Sunil Dutt PLN, Siddalingeshwara KG, Sudipta KM, Karthic J and Shantaveer G. A promising technique for rapid screening and confirmation of L-Glutaminase - A tumour inhibitor from novel Pencillium expansum. International Journal of Pharmaceutical Sciences and Drug Research, 2010; 2 (4): 275-277.

Weingand-Ziade A, Gerber-Decombaz $\mathrm{C}$ and Affolter $\mathrm{M}$. Functional characterization of a salt and thermotolerant glutaminase from Lactobacillus rhamnosus. Enzyme and Microbial Technology, 2003; 32: 862-867.

\section{How to cite this article:}

Savitha S. Desai, Sonal J. Chopra and Basavaraj S. Hungund. Production, purification and characterization of L-Glutaminase from Streptomyces sp. isolated from soil. J App Pharm Sci, 2016; 6 (07): 100-105. 